cja podczas ubiegłorocznego Festiwalu Literatury dla Dzieci w Krakowie wzbudziła ogromne zainteresowanie wśród młodszej i starszej publiczności.

Nadmieńmy jeszcze, że w pierwszej połowie 2019 roku planowane jest ponadto wydanie publikacji będącej zbiorem materiałów IV Międzynarodowej Konferencji Poświęconej Bronisławowi Piłsudskiemu i Jego Dziedzictwu Naukowemu pod redakcją Anny Król i Wioletty Laskowskiej-Smoczyńskiej.

Wioletta Laskowska-Smoczyńska ORCID: 0000-0001-7977-5930

\title{
Uroczystość wręczenia doktoratu honoris causa Uniwersytetu Jana Kochanowskiego w Kielcach profesor Wiktorii Śliwowskiej, 25 kwietnia 2019 roku
}

DOI: $10.19195 / 1429-4168.23 .21$

W Auli Rektoratu Uniwersytetu Jana Kochanowskiego w Kielcach dnia 25 kwietnia 2019 roku, na uroczystym posiedzeniu senatu, odbyła się ceremonia nadania tytułu doktora honoris causa Uniwersytetu Jana Kochanowskiego prof. zw. dr hab. Wiktorii Śliwowskiej — wybitnej polskiej badaczce, szczególnie zasłużonej dla rozwoju badań nad dziejami Rosji, polskich konspiracji i historii Polaków w Rosji, losami polskich zesłańców w XIX wieku, zesłań łagiernych i czasów Rosji Radzieckiej oraz II wojny światowej i Holocaustu. Senat Uniwersytetu Jana Kochanowskiego na wniosek Rady Wydziału Humanistycznego dnia 28 lutego 2019 roku uhonorował dokonania Wiktorii Śliwowskiej dla rozwoju polskiej historiografii, a nawet — jak podkreślił w swojej opinii prof. Andrzej Nowak — „po prostu polskiej humanistyki”.

Uroczystości nadania najwyższego wyróżnienia, jakim może nagrodzić kogoś uczelnia, przewodniczył Jego Magnificencja Rektor prof. dr hab. Jacek Semaniak. W ceremonii wręczenia tytułu doktora honoris causa, którą rozpoczęło odśpiewanie hymnu państwowego, uczestniczyli: laudator, recenzenci, najbliżsi współpracownicy prof. Śliwowskiej, przedstawiciele świata nauki z całego kraju, przyjaciele i uczniowie Pani Profesor oraz przedstawiciele zaprzyjaźnionych uczelni, instytucji kultury i środowisk edukacyjnych, władz centralnych i samorządowych, służb mundurowych, służb i instytucji medycznych, świata biznesu, banków, a także doktoranci i studenci.

Jego Magnificencja Rektor UJK prof. dr hab. Jacek Semaniak w swoim wystąpieniu podkreślił rolę i niezaprzeczalne zasługi Pani Profesor dla rozwoju polskiej nauki i rozpowszechniania jej osiągnięć poza granicami oraz jej wkład w naukę historyczną. Jednocześnie zwrócił uwagę,

że charakterystyczna dla uniwersytetów mnogość dyscyplin naukowych uczy szacunku dla każdej z nich, jako dopełniających się i niezbędnych dla zrozumienia człowieka i rzeczywistości, która go otacza i której cząstkę stanowi. Dlatego też w gronie doktorów honoris causa

Wrocławskie Studia Wschodnie 23, 2019

(C) for this edition by CNS 
odnajdujemy niespotykaną w innych typach uczelni wielość osobowości, których osiągnięcia odnoszą się do różnych, czasami wydaje się odległych od siebie, obszarów nauki i sztuki. Od niektórych wymaga się mozolnego poszukiwania materiałów źródłowych, od niektórych nie mniej mozolnego eksperymentowania, wnikliwych obserwacji mikro- i makrokosmosu, od innych zmagania się ze słowem lub innymi środkami wyrazu decydującymi o rozwoju poezji, literatury i sztuki. Od wszystkich wymaga się dobrego myślenia, które umożliwia poznanie tego, co było niewiadomym. Wspólnoty akademickie, znające wartość dochodzenia do prawd naukowych i nauczania tych prawd, mają możliwość szczególnego honorowania ich autorów. Określenie „,mój mistrz” stanowi wyraz najwyższego uznania dla naukowca i nauczyciela. Dzisiaj kieruję je do Pani Profesor Wiktorii Śliwowskiej, którą społeczność akademicka UJK obdarzyła godnością doctora honoris causa, a opiniujący wniosek promotora o nadanie honorowej godności Pani Profesor wybitni polscy historycy dziejów nowożytnych podkreślili jej rolę, skalę jej dorobku i jego znaczenie dla rozwoju polskiej historiografii.

W dalszej części wystąpienia rektor przytoczył opinie recenzentów. Profesor dr hab. Eugeniusz Niebelski z Katolickiego Uniwersytetu Lubelskiego napisał:

Jako historyk i badacz Wiktoria Śliwowska jest — można rzec — wszechstronna: znawczyni dokumentów i doskonała penetrator archiwów, uważna wydawczyni źródeł, doskonała i odpowiedzialna redaktorka dzieł zbiorowych, ciekawa referentka i dysputant naukowych spotkań i konferencji, rzeczowa inicjatorka nowości badawczych, świetna pisarka i popularyzatorka, odważna i bezkompromisowa publicystka, fachowa thumaczka, autorka wielu wyjątkowych i nieprzemijających książek. Wszystkie dzieła Wiktorii Śliwowskiej cechują się dużymi wartościami merytorycznymi, wiele - doskonałymi walorami literackimi. Jej dorobek oceniało wielu historyków i chyba się nie zdarzyło, by którykolwiek napisał krytycznie, wymieniał mankamenty dyskwalifikujące. Nowa książka Pani Profesor na rynku księgarskim i naukowym czy dzieło zbiorowe przy jej udziale to zawsze było wydarzenie, a w ostatnich dwóch dekadach takich publikacji zwartych powstało wiele. Głęboka mądrość życiowa, rozumienie trudnych czy tragicznych zdarzeń w naszych dziejach, tolerancja, szacunek i współczucie dla ludzi niegdyś skrzywdzonych znalazły swoje odbicie w wielu publikacjach, zwłaszcza zaś w tych o czasach drugiej wojny światowej.

Profesor dr hab. Andrzej Nowak z Uniwersytetu Jagiellońskiego podkreślił natomiast, że:

w tej dziedzinie, to jest na niwie polskiej humanistyki, śmiem twierdzić, jest najwyżej kilka osób, które mogłoby porównywać się z tym, co daje nam 65 lat publikacji Wiktorii Śliwowskiej. Wyobraźmy więc sobie na chwilę, że nie ma tego wszystkiego: tych kilkudziesięciu tomów dokumentów i materiałów do historii powstania styczniowego, konspiracji i zesłań XIX wieku, Holocaustu, kilkudziesięciu także opracowanych lub przetłumaczonych przez Profesor Śliwowską tomów pamiętników, relacji i monografii, że nie ma jej studiów o polskich zesłańcach, o rosyjskich emigrantach, o Hercenie, o Płatonowie, o stosunkach polsko-rosyjskich w XIX wieku... Wyobraźmy to sobie, a zobaczymy wtedy, z jak wielkim i pożywnym - dla całej naszej historiografii, pamięci i kultury - owocem pracowitego życia naukowego mamy w tym wypadku do czynienia. To jest dorobek zasługujący na doktorat honorowy każdej uczelni, która chce mienić się ośrodkiem polskiej historiografii, polskiej rusycystyki czy — po prostu — polskiej humanistyki.

Profesor dr hab. Leszek Zasztowt z Uniwersytetu Warszawskiego w swej opinii zwrócił uwagę, że:

Profesor Wiktoria Śliwowska to nie tylko wybitna historyczka i wspaniała uczona o gigantycznym dorobku naukowym. To także, a może przede wszystkim, niesłychanie dobry i ciepły człowiek, do którego każdy chce się przytulić. Wśród uczniów i kontynuatorów pasji badawczej Pani

Wrocławskie Studia Wschodnie 23, 2019

(C) for this edition by CNS 
Profesor znaleźć można grono osób zajmujących się Rosją, jej historią i współczesnością, jej literaturą i kulturą, jej społeczeństwem i wybitnymi jednostkami — działaczami wolnościowymi filozofami, pisarzami, i politykami. Dla nas wszystkich Wiktoria Śliwowska jest doktorem honoris causa już od dawna. Niechże więc Jej dorobek i postawa zostaną docenione przez Uniwersytet Jana Kochanowskiego. Dla mnie i wielu z nas Pani Profesor zasługuje na to wyróżnienie po dwakroć.

Kończąc, rektor wyraził radość, że po raz kolejny w dziejach uczelni zostanie nadany tytuł doktora honoris causa znamienitej osobie, która całe pracowite życie poświęciła bezgranicznie swojej pasji badawczej, w uznaniu jej wyjątkowej działalności o uniwersalnym i humanistycznym przesłaniu.

Następnie głos zabrał promotor prof. dr hab. Wiesław Caban, który przedstawił sylwetkę Pani Profesor. Wiktoria Śliwowska urodziła się w 1931 roku w Warszawie. Po maturze, w latach 1949-1953 studiowała historię w Instytucie Pedagogicznym im. Aleksandra Hercena w Leningradzie. Tam poznała swojego męża, urodzonego i wychowanego we Francji w rodzinie przedwojennych polskich emigrantów René Śliwowskiego, późniejszego znanego historyka literatury rosyjskiej, krytyka i tłumacza. Po zakończeniu studiów w 1953 roku podjęła pracę w Instytucie Historii Polskiej Akademii Nauk w Warszawie, gdzie w 1960 roku obroniła rozprawę doktorską zatytułowaną Sprawa pietraszewców, opracowaną pod kierunkiem prof. Stefana Kieniewicza, a w 1971 roku otrzymała stopień doktora habilitowanego na podstawie pracy $W$ kręgu poprzedników Hercena. W 1994 roku — po długim oczekiwaniu otrzymała tytuł profesora nauk humanistycznych.

Wiktoria Śliwowska jest człowiekiem instytucją polskiej humanistyki — w swym dorobku ma kilkaset publikacji, w tym kilkadziesiąt książek, z których część była tłumaczona na języki rosyjski, niemiecki, angielski i hiszpański — zasłużoną dla rozwoju badań zarówno w naszym kraju, jak i poza jego granicami. Szczególną rolę w jej dokonaniach odgrywa edytorstwo źródeł. Współpraca z naukowcami rosyjskimi i prof. Kieniewiczem zaowocowała uczestnictwem prof. Śliwowskiej w polsko-rosyjskim zespole (Polska Akademia Nauk i Radziecka/Rosyjska Akademia Nauk), który przez kilkadziesiąt lat penetrował archiwa i rękopiśmienne zbiory (między innymi na terenie Polski, Litwy, Ukrainy, Rosji), a następnie opracowywał i wydawał materiały i dokumenty do dziejów powstania styczniowego. W sumie w ramach tak zwanej żółtej serii opublikowano dwadzieścia pięć tomów źródeł. Zanim jednak zamknięto „żółtą serię”, Wiktoria Śliwowska zaangażowała się w podobnego rodzaju inicjatywę naukową, także we współpracy z Rosjanami, w wyniku której ukazało się osiem obszernych tomów źródeł, dotyczących polskich ruchów niepodległościowych lat czterdziestych XIX wieku, tworzących tak zwaną zieloną serię.

Jednocześnie od początku pracy naukowej wiele miejsca w swych badaniach Pani Profesor poświęcała rosyjskiemu ruchowi demokratycznemu w czasach Mikołaja I i Aleksandra II. Stała się wtedy znawczynią dziewiętnastowiecznej historii Rosji, a wysoko ocenianym przez fachowców efektem badań była książka Mikołaj I i jego czasy. 1825-1855. Wspólnie z mężem René Śliwowskim w 1973 roku opublikowała pracę Aleksander Hercen. Życie $i$ twórczość, dotyczącą jednego z najwybitniejszych działaczy i myślicieli rosyjskich, demokraty, zesłańca, emigranta. W 2017 roku wyszła nowa publikacja o Hercenie autorstwa już tylko Wiktorii Śliwowskiej.

Wrocławskie Studia Wschodnie 23, 2019

(C) for this edition by CNS 
W latach dziewięćdziesiątych XX wieku w centrum zainteresowań Wiktorii Śliwowskiej znalazł się „Polski Sybir”. Wówczas Pani Profesor podjęła działania na rzecz utworzenia kartoteki zesłanych na Syberię spiskowców, powstańców i zesłańców XIX wieku, szczególnie zesłańców postyczniowych. W 1998 roku drukiem ukazała się imponująca publikacja Zesłańcy polscy w Imperium Rosyjskim w I połowie XIX wieku, obejmujące biogramy dwóch i pół tysiąca zesłańców. Wyjątkowe miejsce w syberyjskiej twórczości prof. Śliwowskiej zajmuje wydana w 2005 roku książka Ucieczki z Sybiru, którą wydano również w przekładzie rosyjskim (2014).

Kolejny nurt badań, którego podjęła się Wiktoria Śliwowska, związany był z jej osobistymi przeżyciami czasów II wojny światowej i Holocaustu. W 1993 roku wydała książkę Dzieci Holocaustu mówia... (publikacja ukazała się także w przekładzie niemieckim, angielskim i hiszpańskim).

W twórczości Wiktorii i René Śliwowskich szczególne miejsce zajmuje wydana w 2008 roku książka Rosja nasza miłość. Autorzy znają bowiem Rosję z czasów stalinowskich, odwilży Chruszczowa, tak zwanych czasów zastoju i ostatnich lat, dzięki czemu ich wspomnienia o Rosji, rosyjskiej inteligencji (w tym tej mieszkającej poza jej granicami) i zwykłych ludziach przybierają czasami charakter studium socjologiczno-psychologicznego.

Dopełnieniem pracy naukowej Pani Profesor była działalność w Komisji Historyków Polskich i Radzieckich/Rosyjskich, funkcjonującej w ramach Polskiej Akademii Nauk i Radzieckiej/Rosyjskiej Akademii Nauk. W działalność komisji prof. Śliwowska zaangażowana była praktycznie od momentu jej powstania, to jest od 1965 roku. W latach 1998-2008 przewodniczyła jej ze strony polskiej; jednocześnie z jej inicjatywy zorganizowano kilkanaście konferencji w Polsce i Rosji, które przyczyniły się do rozwoju badań nad stosunkami polsko-rosyjskimi w XIX i XX wieku.

Rosyjska Akademia Nauk doceniła wkład Wiktorii Śliwowskiej w badania nad dziejami Rosji i działania na rzecz rozwoju współpracy naukowej i w 2001 roku nadała jej tytuł doktora honoris causa. Za swój wybitny, wszechstronny dorobek naukowy prof. Śliwowska otrzymała ponadto dwukrotnie nagrodę Klio (1999, 2005), nagrodę specjalną „Przeglądu Wschodniego” (2000) i nagrodę PEN Clubu (2013). W 2003 roku została odznaczona przez prezydenta Rzeczypospolitej Polskiej Krzyżem Oficerskim Orderu Odrodzenia Polski.

Po wygłoszeniu laudacji przez prof. Wiesława Cabana dziekan Wydziału Humanistycznego UJK dr hab. Janusz Detka, prof. UJK, odczytał treść dyplomu:

Senat Uniwersytetu Jana Kochanowskiego w Kielcach na wniosek Rady Wydziału Humanistycznego uchwałą z 31 stycznia 2019 roku nadał tytuł Doctora Honoris Causa prof. zw. dr hab. Wiktorii Śliwowskiej, wybitnej badaczce dziejów Polski i Rosji, autorce wielu znakomitych monografii oraz zbiorów źródeł archiwalnych ocalających pamięć o Polakach uwikłanych w trudne losy obu narodów.

Dyplom podpisali: Promotor — prof. dr. hab. Wiesław Caban, Dziekan — dr hab. Janusz Detka, prof. UJK, Rektor - prof. dr. hab. Jacek Semaniak.

Kielce, 25 kwietnia 2019 r.

Wrocławskie Studia Wschodnie 23, 2019

(C) for this edition by $\mathrm{CNS}$ 
Następnie wraz z rektorem dokonali uroczystego wręczenia dyplomu doktora honoris causa prof. Śliwowskiej, któremu towarzyszyło odśpiewanie przez Chór Akademicki Instytutu Edukacji Muzycznej UJK hymnu Canticorum Jubilo.

Po wręczeniu dyplomu i popiersia Jana Kochanowskiego, które tradycyjnie otrzymuje każdy doctor honoris causa Uniwersytetu Jana Kochanowskiego, kwiatów i pamiątkowych fotografiach wykład wygłosiła Wiktoria Śliwowska. Poświęciła go niezwykłym Polkom zesłanym na Syberię w XIX wieku, kobietom, które poszły za mężami, synami i braćmi na życie tułacze. Pani Profesor podkreśliła, że nie były one jedynie „cieniami” mężczyzn, jak to pięknie ujął Teofil Lenartowicz:

Pójdę za tobą przez krwawe koleje,

Pójdę za tobą na życie tułacze,

Pójdę za tobą przez jasne nadzieje,

Pójdę za tobą przez czarne rozpacze,

Pójdę za tobą przez skonania bramy,

Pójdę za tobą przez nieba słoneczność,

Pójdę za tobą oczyszczenia mgłami,

Przez piekło życia i piekielną wieczność,

Jeśli nas Wyższa Wola nie powoła,

Zgonem w czyściejsze jak dzisiejsze koła ${ }^{1}$.

Zwróciła również uwagę, że zarówno car Mikołaj I, jak i rosyjscy publicyści i historycy uważali je za inicjatorki wszelkich buntowniczych postaw i działań Polaków. Często była przytaczana następująca opinia cara: „nie mam powodu kochania Polaków, ale co do Polek, to ich ścierpieć nie mogę"2.

Wykład Pani Profesor to niezwykła opowieść historyka zajmującego się losami polskich zesłańców i zesłanek syberyjskich, lecz także opowieść o sensie pracy naukowca, który dąży do poznania prawdy. „Największą rozkoszą dla historyka jest obcowanie ze źródłem" - mówił w trakcie seminarium doktoranckiego Stefan Kieniewicz w 1954 roku w Instytucie Historii Polskiej Akademii Nauk. Przez kolejne lata pracy cytat ten nabierał realnego znaczenia. „Rzeczywiście dla historyka odkrywanie źródeł może być rozkoszne" — stwierdziła Pani Profesor. Jednocześnie podkreśliła, że przyznany przez Uniwersytet Jana Kochanowskiego w Kielcach tytuł jest zwieńczeniem jej długiej kariery naukowej.

Z osobistymi gratulacjami pospieszyli historycy z kilku ośrodków akademickich. List gratulacyjny wystosowała Rosyjska Akademia Nauk, na ręce Jego Magnificencji Rektora UJK wpłynęły liczne listy gratulacyjne z wielu ośrodków akademickich w Polsce, w ręce prof. Śliwowskiej gratulacje złożyli też Maria Bożena i Antoni Kuczyńscy z redakcji „Zesłańca” — kwartalnika Rady Naukowej Związku Sybiraków, wyrażając w serdecznych słowach radość z nadania jej tytułu doktora honoris causa. W tym bardzo osobistym adresie czytamy

1 T. Lenartowicz, Wybór poezji, Wrocław 1972, s. 362.

2 Cyt. za: list P. Kisielow do Władystawa Zamoyskiego z 1 maja 1836 roku, [w:] Jenerat Zamoyski, t. 3, Poznań 1914, s. 391. 
Droga Wiktorio, nadanie Ci tego zaszczytnego wyróżnienia jest wyrazem uznania i szacunku dla Twojego naukowo-organizacyjnego trudu dotyczącego polskich ruchów niepodległościowych, a także dziejów Polaków na Syberii. Przez wielolecie w działaniach tych wspierałaś również innych badaczy, wyznając zasadę Mistrza z Czarnolasu wyrażającą się przesłaniem:

„Służmy poczciwej sprawie, a jako kto może, Niech ku pożytku dobra spólnego pomoże"3.

Za ten pożytek, którym wspierałaś także nas, dziękujemy Ci serdecznie.

Uroczystość nadania tytułu doktora honoris causa prof. zw. dr hab. Wiktorii Śliwowskiej zakończyło odśpiewanie hymnu Gaude Mater Polonia przez Chór Akademicki Instytutu Edukacji Muzycznej UJK.

Maria Domańska-Nogajczyk ORCID: 0000-0003-3637-0874

Tomasz Wójcik

ORCID: 0000-0002-5330-0758

3 J. Kochanowski, Pieśni, oprac. M.R. Mayenowa, K. Wilczewska, Wrocław 1992, s. 51. 